Diterima : 8-5-2020 Revisi : 21-6-2020Ｄipublikasi : 25-6-2020

\title{
MENJALIN HUBUNGAN SOSIAL MELALUI KESANTUNAN BERBAHASA
}

\author{
Yuliana Febri Yornai Yonsa \\ SMP N 3 Langke Rembong \\ Jl. Ruteng-Reo Km06, Watu Alo Manggarai, NTT, Indonesia \\ Pos-el :yoonanionn@gmail.com
}

\begin{abstract}
Abstrack
The culture of a society will be reflected in the politeness it implements, including politeness in language. The purpose of this article is to describe the strategies that can be used by the speaker and the interlocutor to achieve good communication, the types of politeness in language, and the ethics used in speaking and speaking. It can be concluded that there are many ethics, manners and courtesy in speaking that are known and adhered to by the community.
\end{abstract}

Keywords : politeness, speak

\begin{abstract}
Abstrak
Budaya suatu masyarakat itu akan tercermin dari kesantunan yang diterapkannya, termasuk kesantunan dalam berbahasa. Tujuan artikel ini untuk mendeskripsikan strategi yang dapat digunakan oleh pembicara dan lawan bicara untuk mencapai komunikasi yang baik, jenis-jenis kesantunan dalam berbahasa, dan etika yang digunakan dalam berbicara dan berbahasa. Dapat disimpulkan ada banyak etika, adab dan sopan santun dalam berbicara yang diketahui dan dianut oleh masyarakat.
\end{abstract}

Kata-kata Kunci : kesantunan, berbahasa

\section{PENDAHULUAN}

Sebagai mahluk sosial, manusia tidak bisa hidup tanpa berhubungan dengan orang lain. Dalam arti kata kita membutuhkan teman untuk saling berkomunikasi. Tujuan kita berkomunikasi kepada lawan bicara itu sendiri adalah untuk menyampaikan pesan dan menjalin hubungan sosial (social relationship). 
Dalam penyampaian pesan tersebut biasanya digunakan bahasa verbal baik lisan atau tulis, atau nonverbal (bahasa isyarat) yang dipahami kedua belah pihak; pembicara dan lawan bicara (Damayanti, 2018). Sedangkan tujuan komunikasi untuk menjalin hubungan sosial dilakukan dengan menggunakan beberapa strategi. Misalnya, dengan menggunakan ungkapan kesopanan (politeness), ungkapan implisit (indirectness), basa-basi (lipsservice) dan penghalusan istilah (eufemisme).

Strategi tersebut dilakukan oleh pembicara dan lawan bicara agar proses komunikasi berjalan baik dalam arti pesan tersampaikan dengan tanpa merusak hubungan sosial diantara keduanya. Dengan demikian proses komunikasi selesai antara pembicara dan lawan bicara mempunyai kesan yang mendalam, misalnya, kesan simpatik, sopan, ramah, dan santun.

Akan tetapi bukanlah hal mudah untuk mencapai dua tujuan komunikasi tersebut. Bahkan seringkali prinsip-prinsip komunikasi sering berbenturan dengan prinsip-prinsip kesopanan dalam berbahasa. Disatu sisi kita diharuskan untuk mematuhi prinsip komunikasi agar tidak terjadi kesalah pahaman, tetapi disisi lain kita harus melanggar prinsipprinsip tersebut, dengan berbasabasi, untuk menjaga hubungan sosial. Dan yang lebih penting lagi kita harus menjaga kesantunan berbahasa di dalam menjalin hubungan sosial antarmanusia.
Seperti yang kita ketahui, masyarakat Indonesia sangat menjunjung kesantunan dalam berbahasa. Maksud yang akan disampaikan tidak hanya berhubungan dengan pemilihan kata, tetapi juga cara penyampaiannya. Sebagai contoh, pemilihan kata yang tepat apabila disampaikan dengan cara kasar akan tetap dianggap kurang santun.

Banyak pendapat yang mengatakan bahwa budaya suatu masyarakat itu akan tercermin dari kesantunan yang diterapkannya, termasuk kesantunan dalam berbahasa. Apalagi setiap masyarakat selalu ada hirarkhi sosial yang dikenakan pada kelompok-kelompok anggota mereka. Hal ini terjadi karena mereka telah menentukan penilaian tertentu, misalnya, antara tua muda, majikan - buruh, guru murid, kaya - miskin, dan status lainnya, ada perbedaan dalam tata cara berbahasa (Salim, 2017). Bahasa yang digunakan ketika berbicara dengan orang yang lebih tua tentu akan berbeda dengan bahasa yang digunakan ketika kita berbicara dengan anak kecil. Selain itu, faktor konteks juga menyebabkan kesantunan perlu diterapkan. Suasana formal atau resmi sangat menekankan kesantunan ini.

Penilaian yang diberikan kepada hirarkhi sosial merupakan penilaian emotif yang diberikan kepada seseorang individu atau kelompok. Penilaian sepeti ini merupakan tanda hormat atau apresiasi kepada yang 
bersangkutan. Kalau diteliti lebih jauh, fenomena ini sudah diterapkan oleh masyarakat kita sejak dulu. Apakah masyarakat yang bahasanya mengenal tingkatan bebahasa (undha-usuk, Jawa) atau tidak mengenalnya (Nababan, 2016). Adapun rumusan masalah yang menjadi ruang lingkup materi pokok bahasan ini adalah seluruh aspek yang berhubungan dengan kesantunan berbahasa dan etika dalam berbahasa seperti: strategi yang dapat digunakan oleh pembicara dan lawan bicara untuk mencapai komunikasi yang baik, jenis-jenis kesantunan dalam berbahasa, dan etika yang digunakan dalam berbicara dan berbahasa.

\section{HASIL KAJIAN DAN PEMBAHASAN}

\section{Kesantunan dalam Berbahasa}

Kesantunan adalah tata cara, adat, atau kebiasaan yang berlaku dalam suatu masyarakat. Kesantunan merupakan aturan perilaku yang ditetapkan dan disepakati bersama oleh suatu masyarakat tertentu sehingga kesantunan sekaligus menjadi persyarat yang disepakati oleh perilaku sosial.

Dalam pergaulan sehari-hari kesantunan dapat dilihat dari berbagai segi, yaitu: Pertama, kesantunan memperlihatkan sikap yang mengandung nilai sopan santun atau etiket dalam pergaulan sehari-hari. Ketika orang dikatakan santun, maka dalam diri seseorang itu tergambar nilai sopan santun atau nilai etiket yang berlaku secara baik di masyarakat tempat seseorang itu megambil bagian sebagai anggotanya. Ketika dia dikatakan santun, masyarakat memberikan nilai kepadanya, baik penilaian itu dilakukan secara seketika (mendadak) maupun secara konvensional (panjang, memakan waktu lama). Sudah barang tentu, penilaian dalam proses yang panjang ini lebih mengekalkan nilai yang diberikan kepadanya.

Kedua, kesantunan sangat kontekstual, yakni berlaku dalam masyarakat, tempat, atau situasi tertentu, tetapi belum tentu berlaku bagi masyarakat, tempat, atau situasi lain. Ketika seseorang bertemu dengan teman karib, boleh saja dia menggunakan kata yang agak kasar dengan suara keras, tetapi hal itu tidak santun apabila ditujukan kepada tamu atau seseorang yang baru dikenal. Mengecap atau mengunyah makanan dengan mulut berbunyi kurang sopan kalau sedang makan dengan orang banyak di sebuah perjamuan, tetapi hal itu tidak begitu dikatakan kurang sopan apabila dilakukan di rumah.

Ketiga, kesantunan selalu bipolar, yaitu memiliki hubungan dua kutub, seperti antara anak dan orangtua, antara orang yang masih muda dan orang yang lebih tua, antara tuan rumah dan tamu, antara pria dan wanita, antara murid dan guru, dan sebagainya. 
Keempat, kesantunan tercermin dalam cara berpakaian (berbusana), cara berbuat (bertindak), dan cara bertutur (berbahasa).

\section{Jenis Kesantunan}

Berdasarkan penjelasan di atas, kesantunan dapat dibagi tiga, yaitu kesantunan berpakaian, kesantunan berbuat, dan kesantunan berbahasa. Kecuali berpakaian, dua kesantunan terakhir tidak mudah dirinci karena tidak ada norma baku yang dapat digunakan untuk kedua jenis kesantunan itu.

Dalam kesantunan

berpakaian (berbusana, berdandan), ada dua hal yang perlu diperhatikan. Pertama, berpakaianlah yang sopan di tempat umum, Kedua, berpakaianlah yang rapi dan sesuai dengan keadaan, yaitu berpakaian resmi pada acara resmi, berpakaian santai pada situasi santai, berpakaian renang pada waktu renang.

Kesantunan perbuatan adalah tatacara bertindak atau gerak-gerik ketika menghadapi sesuatu atau dalam situasi tertentu.misalnya ketika menerima tamu, bertamu ke rumah orang, duduk di ruang kelas, menghadapi orang yang kita hormati, berjalan di tempat umum, menunggu giliran (antre), makan bersama di tempat umum, dan sebagainya. Masingmasing situasi dan keadaan tersebut memerlukan tatacara yang berbeda. Pada waktu makan bersama, misalnya, memerlukan kesantuan dalam cara duduk, cara mengambil makanan, cara makan atau mengunyah, cara memakai sendok, cara membersihkan mulut setelah makan, dan cara memakai tusuk gigi. Salah satu contoh mengenai kesantunan dalam tindakan, misalnya sangat tidak santun apabila kita berwajah murung ketika menerima tamu, duduk dengan kaki diselonjorkan ketika mengikuti kuliah dosen, bertolak pinggang ketika berbicara dengan orang tua, mendahului orang lain dengan bersenggolan badan atau ketika berjalan di tempat umum tanpa sebab, nyelonong ke loket ketika yang lain sedang antre menanti giliran, menguap selebarlebarnya sambil mengeluarkan suara di depan orang lain, dan mencungkil gigi tanpa menutup mulut ketika sedang makan bersama di tempat umum.

Kesantunan

berbahasa tercermin dalam tatacara berkomunikasi lewat tanda verbal atau tata cara berbahasa. Ketika berkomunikasi, kita tunduk pada norma-norma budaya, tidak hanya sekedar menyampaikan ide yang kita pikirkan. Tatacara berbahasa harus sesuai dengan unsur-unsur budaya yang ada dalam masyarakat tempat hidup dan dipergunannya suatu bahasa dalam berkomunikasi.

Apabila tatacara berbahasa seseorang tidak sesuai dengan norma-norma budaya, maka ia akan mendapatkan nilai negatif, misalnya dituduh sebagai orang yang sombong, angkuh, tak acuh, egois, tidak beradat, bahkan tidak berbudaya. 
Tata cara berbahasa sangat penting diperhatikan para peserta komunikasi (komunikator dan komunikan) demi kelancaran komunikasi. Oleh karena itu, masalah tata cara berbahasa ini harus mendapatkan perhatian, terutama dalam proses belajar mengajar bahasa. Dengan mengetahui tatacara berbahasa diharapkan orang lebih bisa memahami pesan yang disampaikan dalam komunikasi karena tatacara berbahasa bertujuan mengatur serangkaian hal berikut.

a. Apa yang sebaiknya dikatakan pada waktu dan keadaan tertentu.

Contoh: jika lagi berbicara di forum resmi sebaiknya tidak banyak bercanda dan ngobrol sendiri dengan teman. lebih menghormati forum dan orang yang sedang berbicara.

b. Ragam bahasa apa yang sewajarnya dipakai dalam situasi tertentu.

Contoh: ragam bahasa yang dipakai harus sesuai dengan situasi. Jika di forum resmi bahasa yang dipakai bahasa Indonesia yang baik dan benar.tidak di campur-campur bahasa Indonesia dengan bahasa inggris atau bahasa Indonesia dengan bahasa daerah.

c. Kapan dan bagaimana giliran berbicara dan pembicaraan sela diterapkan.

Contoh:waktu yang tepat untuk berbicara adalah sela waktu
Tanya jawab. berbicara yang baik apabila berbicara tidak memotong pembicaraan orang.

d. Bagaimana mengatur kenyaringan suara ketika berbicara.

Contoh: intonasi suara sangat diperlukan dalam berbicara, berbicara terlalu nyaring(keras) itu tidak baik dan berbicara terlalu pelan itu juga tidak baik. Intonasi berbicara yang baik adalah yang tidak keras dan tidak pelan atau sedang-sedang saja.

Suatu kebudayaan yang sudah mendarah daging pada diri seseorang sangat berpengaruh pada pola berbahasanya. Oleh sebab itu, kita perlu mempelajari atau memahami norma-norma budaya sebelum mempelajari bahasa. Sebab, tatacara berbahasa yang mengikuti norma-norma budaya akan menghasilkan kesantunan berbahasa.

\section{SIMPULAN}

Berbicara adalah kebutuhan kita sebagai manusia. Berbicara merupakan salah satu cara yang efektif bagi kita untuk berkomunikasi. Dengan berbicara kita bisa menyampaikan maksud dan tujuan serta buah pikiran kita dengan cepat. Akan sangat bijaksana jika kita memperhatikan cara berbicara maupun isi dan materi yang kita bicarakan. Ada banyak etika, adab dan sopan santun dalam berbicara yang diketahui dan dianut oleh masyarakat. 


\section{DAFTAR PUSTAKA}

Damayanti, Rini. (2018). Register dalam Komunikasi Waria di Kembang Kuning Surabaya. Jurnal Ilmiah Universitas Hamzanwadi NTB. SeBaSa 1 (2), 142-152

Nababan, PWJ. (2016). Sosiolinguistik: Suatu Pengantar. Jakarta: PT Gramedia.

Salam, H Burhanuddin. (2017). Etika Sosial: Asas Moral dalam Kehidupan Manusia. Jakarta: PT Rineka Cipta. 